\title{
ROLE OF HYDROGEN IN PRODUCTION OF MATERIALS FOR SPACE-SYSTEM ENGINEERING BY POWDER METALLURGY METHODS
}

\author{
Trefilov V. I , Skorokhod V. V., Morozov I. A., Morozov R. O., Dubovik T. V.. \\ Timofeyeva I. I., Dobrovolsky V. D., Panashenko V. M. \\ Institute for Problems of Material Science of NAS Ukraine, Kyiv
}

\section{Titanium hydride with increased hydrogen content}

Hydrogen and compounds of hydrogen with metals (metal hydrides) are widely used in different industry branches as follows: 1) the reductants of especially stable oxides in mining of tungsten, molybdenum, indium, cobalt, germanium, nickel, rhenium; 2) the catalysts in polymerization of organic compounds (olefins, pentanes, cycloalkanes, ethylene, maleic and fumarole acids) and in synthesis of ammonia; 3 ) the precursor for producing of ceramicals and intermetallics; 4) the activators of sintering reactions for manufacturing of products from metal and ceramic powders; 5) the biological protection materials against irradiation; 6) component of solid fuel; 7) the source of ecological safe fuel.

The application fields of metal hydrides and hydrogen, as well as its influence on physical-chemical processes activation and production qualitative adjectives, depend on hydrogen content of compounds.

When comparing the possibilities of practical production use of the metal hydrides (Table 1), the hydrides of IV Group metals are the most attractive as materials which have the highest specific density of hydrogen atoms.

Since in 50-ies, attempts to increase the hydrogen contents in hydrides of IV Group metals have resulted in creation of technologies, with hydrogen in accordance with formula $\mathrm{MeH}_{2}$, i.e. no more than two atoms of hydrogen per one metal atom. The industrial hydrides include not more than 1.8-1.85 atoms of hydrogen. The theoretical investigations show that the structure of binary hydrides of IV Group metals can be much higher than $\mathrm{MeH}_{2}$ and specific density of hydrogen atoms in $\mathrm{TiH}_{3}$ will be 13.68 .

At the Institute for Problems of Materials Science of NAS Ukraine developed fundamentals of new technology of activation and saturation of materials with gases. The approach with using new techniques showed itselves worth when studying interaction of hydrogen with IV Group transition metals ( $\mathrm{Ti}, \mathrm{Zr}$, Hf). It allowed to synthesize titanium hydride with anomalously increased hydrogen content.

The purpose of the research work was creation of technologycal bases of synthesis of hydrides of IV Group metals ( $\mathrm{Ti}, \mathrm{Zr}$, Hf) with increased hydrogen content and study of their physical and chemical properties.

\footnotetext{
*imorozov@materials.kiev.ua (for Dubovik T.V.)
} 
To prepare titanium hydride with increased hydrogen content $\left(\mathrm{TiH}_{\mathrm{x}>2}\right)$ for studying its properties a titanium of «iodide» purity and hydrogen gas were used. Hydrogen gas was prepared by decomposition of metal hydride and titanium was in the form of a thin chip. An apparatus of Sieverts-type was used for hydration.

In order to study the dependence of hydrogen content on the temperature and duration of hydrogenation the 46 technological regimes of titanium hydride production were tested (temperature range 1273-573 K; temperature was varied by steps of 50 degrees with exposure of $30,60,90 \mathrm{~min}$ ). As a result the regimes were defined which allow to obtain the hydrides of composition $\mathrm{TiH}_{\mathrm{x}}$ with $\mathrm{x}=2.14-3.8$.

For preliminary measurement of hydrogen content the gravimetric method was used which based on the measuring the quantity of water is produced by burning the hydrogen from hydride in oxygen flow. This method is classic one for hydrogen quantity determination. However the consistent results could be obtained only for hydrides of $\mathrm{TiH}_{\mathrm{x}}<2$. This is due to the high thermal stability of hydrides $\mathrm{TiH}_{\mathrm{x}>2}$ and their specific features. In the present study this method is employed only for choosing the samples for further investigations.

Four samples of titanium hydride were selected for final hydrogen content measurement. Based on gravimetric measurements these samples contain maximum of hydrogen. The results of hydrogen content measurement by different methods are listed in Table 2.

X-ray examination of the samples was realized with diffractometer DRON-3 in $\mathrm{CuK}_{\alpha}$ radiation at two temperatures: $295 \mathrm{~K}$ and $285 \mathrm{~K}$. The lattice parametrers were calculated through the reflection line (222) because it does not exhibit the influence of lattice tetragonal origin (Table 3). As is evident from the results the lattice parameters and the volume of elementary cell increase with the increase in the hydrogen content.

The low-temperature X-raying of titanium hydrides with different powders the diffractometer DRON-0,5 was employed and $\mathrm{CuK}_{\alpha}$ radiation in low-temperature unit was used. Through the diffractograms obtained in the temperature range of 295-83 K the crystal lattice parameters of hydride phases (tetragonal and cubic) were calculated and the dependencies of those parameters on the temperature were also obtained.

With this data the volumes of crystal lattice elementary cell of hydride phases were calculated and their variation with the temperature lowering was revealed. The results obtained showed that the higher the hydrogen content in hydride phase, the more the volume of crystal lattice elementary cell at all temperatures and it considerably exceeds the volume of elementary cell of metallic titanium.

It was revealed experimentally that the temperature compressibility of hydrides crystal lattice at low temperatures depends on the hydrogen content and is the less, the more is the hydrogen quantity in titanium hydride.

Thus it could be concluded that tetragonal transformation of hydrides cubic structure at low temperature is associated with the redistribution of hydrogen atoms between tetra- and 
octapositions at high hydrogen quantity in lattice. At low hydrogen content its transition into the octapositions even at low temperature does not take place. This does not result in tetragonal distortion of lattice but causes its more compression.

At high temperatures in hydrides with composition of $\mathrm{TiH}_{2}(\mathrm{x} \geq 2)$ the part of hydrogen atoms fills up the octapores. When lowering the temperature the hydrogen atom turn into tetrapores thus causing the tetragonal distortion of crystal lattice similar to the case of martensite [1].

\section{Increasing of non-metal nitrides characteristics under the influense of hydrogen}

The method of hydrogen-thermal treatment (HTT) of powders of non-metal refractory compounds $\left(\mathrm{BN}, \mathrm{AlN}, \mathrm{Si}_{3} \mathrm{~N}_{4}\right)$ was developed at the Institute and it is of great interest $[2,3]$. HTT of the powders activates the processes of volume shrinkage of bricks at sintering, allows to decrease the temperature and time of sintering, to get sintered ware with higher values of density, strength and electrical resistivity. Using of HTT promotes creation of new hightemperature composite materials with assigned structure and necessary service characteristics.

Non-metal nitrides exhibit high mechanical strength, thermal stability, chemical stability as well as specific dielectric properties and high heat conductivity. That is why these compounds make a foundation for creation of composite materials of wide destination.

Low defect concentration and mobility as well as hindering of diffusion processes are known to be characteristic of crystal lattice of non-metal nitrides. Moreover it should be kept in mind that in sintering not all powder surface takes part. The considerable powder surface is passivated with atoms of chemisorped impurities which deteriorate the sintering.

Proposed approach to the sintering activation consists in hydrogen-thermal treatment of precursor non-metal nitrides powders at $1000^{\circ} \mathrm{C}$ in presence of hydrogen and catalysts.

TEM and SEM investigation revealed the granulometric compositions of AlN powder in initial state and after HTT to be considerably different. Thus the results of study show that HTT of AlN powder at $1150{ }^{\circ} \mathrm{C}$ favour to purification from oxygen and change in granulometic composition due to breakdown of film connections between particles in aggregates. The structure-morphological changings in $\mathrm{Si}_{3} \mathrm{~N}_{4}$ powder with increase in temperature of HTT to proceed in the following sequence: some loosening of aggregates and fragments with forming more dense packing of particles $\left(800-900{ }^{\circ} \mathrm{C}\right)$; further fragmentation of aggregates and initial stage of bridge connection formation between particles in fragments $\left(1000^{\circ} \mathrm{C}\right)$; full breakdown of initial aggregates and formation the monolithic granules with bridge connections between granules $\left(1150{ }^{\circ} \mathrm{C}\right)$. HTT of $\mathrm{BN}$ powders at $800^{\circ} \mathrm{C}$ favours the breakdown of porous bulky aggregates and activates the mass transfer processes through surface diffusion; the same at $1150^{\circ} \mathrm{C}$ results in forming the monolithic aggregates of rounded shape.

In order to study densification process and the structure forming of compact materials in sintering the samples were made from $\mathrm{AlN}, \mathrm{Si}_{3} \mathrm{~N}_{4}$ and $\mathrm{BN}$ powders both untreated and treated with HTT. The samples made of powders treated with HTT are densified in sintering 
significantly better than those made of untreated powders: $\mathrm{Si}_{3} \mathrm{~N}_{4}$ - in 2 times, AlN - in 3-4 times. Positive effect of hydrogen-thermal treatment on $\mathrm{AlN}, \mathrm{Si}_{3} \mathrm{~N}_{4}$ and $\mathrm{BN}$ powder sintering is manifested through activation of mass transfer processes. The same processes determine also the grain structure formation. The sintered samples made of HTT treated powders differ in less mean grain size, more part of anisometric grains and availability of high-dense formations from disperse grains (zone inclusions) (see table 4).

Interaction of samples of non-metal nitrides (manufactured from powders after HTT) with melts of steel, brass, zinc, iron and copper were studied. Investigation of character of interatomic interaction of $\mathrm{BN}, \mathrm{AlN}$ and $\mathrm{Si}_{3} \mathrm{~N}_{4}$ at contacting with melted metals showed that samples of that nitrides didn't change its chemical composition in above-mentioned melts, i.e. chemical interaction of the materials with the melts were absent. Layers formed on the surface of the materials as a result of interaction of melted metal atoms with oxydes and other impurities which were on the surface of the materials. Diffusion into melt and solution of this impurities in the liquid metals results in purificatrion of materials surface.

From comparison of wetting angles for nitrides with the same melt the following sequence was revealed: $\theta_{\mathrm{Si}_{3} \mathrm{~N}_{4}}<\theta_{\mathrm{AlN}}<\theta_{\mathrm{BN}}$. It is at the bottom of statement that boron nitride has the most stability among these nitrides in above-mentioned melts.

The nitride materials developed can be used in space-system engineering as hightemperature insulators, as wide band dielectrics, as refractory crucibles for fusion of metals and alloys, as friction bearings, as details for combustion chambers and gas turbines, as radio transparent shields, etc.

1. Kurdjumov G. V,.Khachaturyan A. Q, Met.Trans., 3, 1069, 1972.

2. Trefilov V. I., Morozov I. A., Morozova R. A., et al. Effect of Hydrogen on improving purity of WC and AIN Powders // Int J. Hydrogen Energy. - 1996. - 21, No. 11-12. - P. 1097-1099.

3. Morozova R. A., Morozov I. A., Itsenko A. I., et al. Study the influence of hydrogen-thermal treatment on the structure state of non-metal nitride powders // Abstracts of NATO Int Conf «Hydrogen Materials Science and Chemistry of Metal Hydrides». ICHMS'99. 1999. p. 254-255. 
Table 1. Hydrogen content in some substances

\begin{tabular}{|c|c|c|c|}
\hline Substance & $\begin{array}{c}\text { Density, } \\
\mathrm{kg} / \mathrm{m}^{3}\end{array}$ & $\begin{array}{c}\text { Volume of } \mathrm{H}_{2} \\
\text { (in liters) per } 1 \mathrm{sm}^{3} \\
\text { of hydride }\end{array}$ & $\begin{array}{c}\text { Quantity of H atoms } \\
\text { per } 1 \mathrm{sm}^{3}, \times 10^{22}\end{array}$ \\
\hline \hline $\mathrm{TiH}_{3.7}$ & $3600-3850$ & $2.87-3.07$ & $15.54-16.62$ \\
\hline $\mathrm{TiH}_{3}$ & $3600-3850$ & $2.36-2.53$ & $12.77-13.66$ \\
\hline $\mathrm{VH}_{2}$ & 4630 & 1.946 & 10.53 \\
\hline $\mathrm{TiH}_{2}$ & 3779 & 1.685 & 9.12 \\
\hline $\mathrm{AlH}_{3}$ & 1480 & 1.647 & 8.92 \\
\hline $\mathrm{HfH}_{2}$ & 11370 & 1.402 & 7.58 \\
\hline $\mathrm{ZrH}_{2}$ & 5680 & 1.356 & 6.69 \\
\hline $\mathrm{LaH}_{3}$ & 5260 & 1.237 & 6.69 \\
\hline $\mathrm{H}_{2} \mathrm{O}$ & 1000 & 1.236 & 4.05 \\
\hline $\mathrm{TaH}_{0.8}$ & 15300 & 0.749 & 4.07 \\
\hline $\mathrm{paraffin}^{*}$ & 952 & 0.753 & 5.22 \\
\hline $\mathrm{H}_{2} \cdot$ solid & 86.71 & 0.964 & 4.65 \\
\hline $\mathrm{H}_{2} \cdot$ liquid & 77.2 & 0.859 & 0.01 \\
\hline $\mathrm{H}_{2 \cdot}{ }^{*}{ }^{*}$ & 0.13 & - & \\
\hline & & & \begin{tabular}{c} 
\\
\hline
\end{tabular} \\
\hline
\end{tabular}

* _ density indicated at triple point parameters. Density of hydrogen at normal conditions is $89.87 \mathrm{~g} / \mathrm{m}^{3}$ 
Table 2. Hydrogen content in $\mathrm{TiH}_{\mathrm{x}}$ as stated by different methods

\begin{tabular}{|c|c|c|c|c|c|c|}
\hline \multirow{3}{*}{ Sample } & \multicolumn{6}{|c|}{ Investigation methods } \\
\hline & \multirow[t]{2}{*}{ Leco } & \multirow{2}{*}{$\begin{array}{c}\text { Mass- } \\
\text { spectrometric }\end{array}$} & \multicolumn{2}{|c|}{ Chemical } & \multicolumn{2}{|c|}{ Nuclear } \\
\hline & & & Sulphur acid & Chlorhydric acid & MKC-01P & DINA* \\
\hline $\begin{array}{c}1.00 \\
\text { (industr.) }\end{array}$ & 1.95 & $1.88 \pm 0.12$ & $1.91 \pm 0.15$ & $1.95 \pm 0.15$ & $1.8 \pm 0.15$ & $1.8 \pm 0.3$ \\
\hline 1.04 & 1.83 & $2.27 \pm 0.12$ & - & - & $2.97 \pm 0.15$ & $3.7 \pm 0.3$ \\
\hline 1.07 & 1.90 & $2.52 \pm 0.12$ & $2.34 \pm 0.15$ & $2.31 \pm 0.15$ & $3.10 \pm 0.15$ & $3.8 \pm 0.3$ \\
\hline 1.10 & 1.83 & $2.32 \pm 0.12$ & - & - & $3.41 \pm 0.15$ & $3.6 \pm 0.3$ \\
\hline 1.13 & 1.90 & $2.14 \pm 0.12$ & - & - & $1.85 \pm 0.15$ & $2.0 \pm 0.3$ \\
\hline
\end{tabular}

* data can be considered as estimates though they correlate with the results were obtained with MKC-01P

Table 3. Crystal-chemical characteristics of hydrides

\begin{tabular}{|c|c|c|c|c|c|c|}
\hline \multirow{2}{*}{ Sample } & \multicolumn{3}{|c|}{ Lattice parameters, $\mathrm{nm}$} & \multicolumn{2}{|c|}{$\begin{array}{c}\text { Elementary cell } \\
\text { volume, } 10^{2} \mathrm{~nm}^{3}\end{array}$} & $\mathrm{I}_{(11)} / \mathrm{I}_{(200)}$ \\
\cline { 2 - 7 } & at $285 \mathrm{~K}$ & at $295 \mathrm{~K}$ & \multicolumn{2}{|c|}{} \\
\cline { 2 - 7 } & $\mathrm{a}$ & $\mathrm{c}$ & $\mathrm{a}$ & at $285 \mathrm{~K}$ & at $295 \mathrm{~K}$ & \\
\hline \multicolumn{7}{|c|}{} \\
\cline { 2 - 7 } & 0.4478 & 0.4369 & 0.4448 & 8.76 & 8.80 & 3.7 \\
\hline 1.00 & 0.4479 & 0.4392 & 0.4458 & 8.81 & 8.86 & 2.8 \\
\hline $\mathrm{TiH}_{1.97} *$ & - & - & 0.4454 & - & 8.84 & - \\
\hline
\end{tabular}

* Literature data 
Table 4. Grain structure of sintered samples made from $\mathrm{AlN}, \mathrm{Si}_{3} \mathrm{~N}_{4}$ and $\mathrm{BN}$ powders

\begin{tabular}{|c|c|c|}
\hline $\begin{array}{l}\text { Samples made } \\
\text { from powders }\end{array}$ & Structural components, $\mu \mathrm{m}$ & Grain characteristics \\
\hline Untreated AlN & $\begin{array}{l}0.3-1.0 \\
3.0-5.0\end{array}$ & $\begin{array}{l}\text { Equi-axial form }(80 \%) \text {. } \\
\text { Granules }(20 \%) \text {. }\end{array}$ \\
\hline AlN after HTT & $\begin{array}{l}0.5-1.6 \\
2.0-3.0\end{array}$ & $\begin{array}{l}\text { Equi-axial form }(95 \%) \text {. } \\
\text { Granules }(5 \%) \text {. }\end{array}$ \\
\hline Untreated $\mathrm{Si}_{3} \mathrm{~N}_{4}$ & $0.2-0.3$ & $\begin{array}{l}\text { Equi-axial form }(90 \%) \text {. } \\
\text { Anisometric }(10 \%) \text {. }\end{array}$ \\
\hline $\mathrm{Si}_{3} \mathrm{~N}_{4}$ after $\mathrm{HTT}$ & $\begin{array}{l}0.1-0.3 \\
1.0-1.5\end{array}$ & $\begin{array}{l}\text { Equi-axial form }(60 \%) \text {. } \\
\text { Anisometric }(20 \%) \text {. } \\
\text { Zone densifications, aggre- } \\
\text { gates }(20 \%) \text {. }\end{array}$ \\
\hline Untreated BN & $\begin{array}{c}3-10 \\
\text { plane }(0001)\end{array}$ & $\begin{array}{l}\text { Intercrossed twins; } \\
\text { disoriented sections }\end{array}$ \\
\hline $\mathrm{BN}$ after HTT & $\begin{array}{c}2-7 \\
\text { plane }(0001)\end{array}$ & $-"$ " - \\
\hline
\end{tabular}

